\title{
ANALYSIS OF COMPETITIVENESS OF INDUSTRIAL ENTERPRISES OF ZAPORIZHZHIA DISTRICT OF ZAPORIZHZHIA REGION
}

\author{
Tkachenko S. \\ Classic Private University \\ Ukraine, 69000, Zaporizhzhia, Zhukovsky str., 84 \\ space7770@ukr.net \\ ORCID 0000-0002-3798-5902
}

Key words:

Zaporizhzhia district of Zaporizhzhia region, competitiveness, industrial enterprises.
This article analyses of the competitiveness of industrial enterprises of the Zaporizhzhia district of the Zaporizhzhia region. The results of the research identify unique features that led to the effective functioning and development of industrial enterprises in the Zaporizhzhia district of the Zaporizhzhia region. These features are many-sided and fairly complex, and are closely connected with the general development of industrial production, adaptation of enterprises to the market environment and the necessity of increase competitiveness of products, enterprises, industry in general. In the article, the process of development of competition relations in this sphere and the problem of increasing competitiveness of products of industrial enterprises are examined as pre-conditions of achieving strategic aims of enterprise development. It is reasonable that one of the effective methodical instruments of stimulation of organizational, economic, technological and technical factors to increase enterprise competitiveness in the Zaporizhzhia district is adopting the logistic approach in modern terms. Attention is accented on the need of continual planning and modifying the competitiveness control system on the basis of logistic principles that have a two-tier structure. Therefore, effective activity of industrial enterprises in a competition environment means that their production as well as marketing strategy must correspond to the consumer demand as much as possible and provide maximal recoupment of both capital and the capital goods. A conclusion is made that competitiveness is a crucial condition of economic survival for an industrial enterprise, and should be the object of permanent attention and the goal of effective management. The study also points out a series of strategic priorities for developing a control system of competitiveness for industrial enterprises. In addition, a chart of the model for increasing competitiveness of industrial enterprises based on the logistic approach is provided. Thus, the aforementioned problems together with the urgent need of focusing on the strategic level of developing tools to increase competitiveness of industrial enterprises on the basis of the logistic approach, define a need for this article.

\section{АНАЛІЗ КОНКУРЕНТОСПРОМОЖНОСТІ ПРОМИСЛОВИХ ПІДПРИЄМСТВ ЗАПОРІЗЬКОГО РАЙОНУ ЗАПОРІЗЬКОЇ ОБЛАСТІ}

Ткаченко С.M.

Класичний приватний університет

Украӥна, 69000, м. Запоріжжя, вул. Жуковського, 84

\begin{abstract}
Ключові слова:
Запорізький район Запорізької області, конкурентоспроможність, промислові підприємства.
\end{abstract}

У статті розглянуто аналіз конкурентоспроможності промислових підприємств Запорізького району Запорізької області. В результаті дослідження виявлені особливості формування ефективного функціонування i розвитку промислових підприємств в Запорізькому районі Запорізької області, яке є багатогранним і досить складним, оскільки тісно пов'язане із загальним розвитком промислового виробництва, адаптацією підприємств до ринкового середовища i необхідністю підвищення конкурентоспроможності продукції, підприємств, галузі в цілому. У статті процес розвитку конкурентних стосунків в цій сфері і проблема підвищення конкурентоспроможності продукції промислових підприємств розглядаються як передумова досягнення стратегічних цілей розвитку підприємства. Обгрунтовано, що одним 3 дієвих методичних інструментів стимулювання організаційних, економічних, технологічних та технічних факторів підвищення конкурентоспроможності підприємств в Запорізькому районі Запорізької області в сучасних умовах $є$ логістичний підхід. Акцентовано увагу на те, що слід також прагнути до безперервності планування та контролю функціонування системи управління конкурентоспроможністю на основі логістичних принципів який має дворівневу структуру. Тож, ефективна діяльність промислових підприємств 
в конкурентному середовищі означає, що їх виробнича та маркетингова діяльність повинна максимально повно відповідати споживчому попиту, забезпечувати максимальну окупність засобів виробництва i капіталу. Зроблено висновок що конкурентоспроможність $є$ найважливішою умовою економічного виживання промислового підприємства, об'єктом постійної уваги і метою ефективного менеджменту. Визначено порядок стратегічних пріоритетів розвитку системи управління конкурентоспроможністю підприємств промисловості. Показана схема впровадження моделі підвищення конкурентоспроможності підприємств промисловості на основі логістичного підходу. Отже, означені проблеми, поряд з необхідністю першочергової уваги до стратегічного рівня формування інструментарію підвищення конкурентоспроможності промислових підприємств на основі логістичного підходу, визначили актуальність теми даної наукової статті.

\section{Statement of the problem}

The problem of the effective functioning and development of industrial enterprises in the Zaporizhzhia district of the Zaporizhzhia region is many-sided and difficult enough, as closely constrained with general development of industrial production, adaptation of enterprises to the market environment and necessity of increase of competitiveness of products, enterprises, industry on the whole. Therefore, the process of development of competition relations in this sphere and problem of increase of competitiveness of products of industrial enterprises are examined as pre-condition of achievement of strategic aims of development of enterprise.

One of effective methodical instruments of stimulation of organizational, economic, technological and technical factors of increase of competitiveness of enterprises in the Zaporizhzhia district of the Zaporizhzhia region there is logistic approach in modern terms [1]. Application of this approach allows substantially to become better maintenance of clientele, to reduce the term of delivery of loads, promote efficiency of the use of transport, accept scientifically-reasonable decisions at the decision of certain tasks to development of enterprise [2, p. 98100], by a consequence what an increase of competitiveness of products and enterprises is in the Zaporizhzhia district of the Zaporizhzhia region on the whole. It follows also to aspire to continuity planning and control of functioning of control system by a competitiveness on the basis of logistic principles. This control must have a two-tier structure: strategic control of management processes and tactical (operative, current) control.

The marked problems, next to the necessity of near-term attention to the strategic level of forming of tool of increasing competitiveness of industrial enterprises on the basis of logistic approach, defined actuality of theme of this scientific article.

During 2019 certain measures were used on an upturn in the economy in the Zaporizhzhia district of the Zaporizhzhia region, terms were created for the normal vital functions of population of district in accordance with tasks certain in Program of socio-economic and cultural development of regional on 2019.

The analysis of basic indexes of socio-economic development of the Zaporizhzhia district of the Zaporizhzhia region testifies for 2019, that the work, sent to development and stabilizing of industries of economy of district, providing of acuestss to the budgets of all levels (table.1), is conducted in a district [3].

Table 1 Dynamics of basic indicators of socio-economic development of the Zaporizhzhia district of the Zaporizhzhia region [3]

\begin{tabular}{|l|l|l|l|l|}
\hline Indexes & unit & $\begin{array}{l}2018 \\
\text { (report) }\end{array}$ & $\begin{array}{l}2019 \text { (ex- } \\
\text { pected }\end{array}$ & $\begin{array}{l}2020 \\
\text { (prognosis) }\end{array}$ \\
\hline $\begin{array}{l}\text { Volume of the realized industrial products } \\
\text { (commodities, services) }\end{array}$ & $\begin{array}{l}\text { millions of } \\
\text { hryvnyas }\end{array}$ & 2314,0 & 2600,0 & 2940,0 \\
\hline $\begin{array}{l}\text { Gross products of agriculture are on all categories of } \\
\text { economies in the permanent costs of 2010 }\end{array}$ & $\begin{array}{l}\text { millions of } \\
\text { hryvnyas }\end{array}$ & 328,9 & 338,9 & 331,1 \\
\hline $\begin{array}{l}\text { Index of agricultural produce of to previous year for } \\
\text { to the agricultural enterprises }\end{array}$ & $\%$ & 117,7 & 103,0 & 97,7 \\
\hline $\begin{array}{l}\text { Capital investments are on enterprises and organizations } \\
\text { of all patterns of ownership (in actual prices) }\end{array}$ & $\begin{array}{l}\text { millions of } \\
\text { hryvnyas }\end{array}$ & 204,6 & 246,0 & 295,2 \\
\hline $\begin{array}{l}\text { An average monthly salary of one regular worker is } \\
\text { on a regional }\end{array}$ & \begin{tabular}{l} 
rpH. \\
\hline Rate of increase of average monthly salary
\end{tabular} & 7053,44 & 8970,36 & 10764,40 \\
\hline Amount of small enterprises & units & 364 & 127,2 & 120 \\
\hline Amount of small enterprises (at \% a to previous year) & $\%$ & 364 & 370 \\
\hline Amount of middle enterprises & units & 7 & 105,2 & 101,6 \\
\hline Amount of middle enterprises (at \% a to previous year) & $\%$ & 100 & 100 & 7 \\
\hline
\end{tabular}




\section{Analysis of recent studies and publications}

Among home and foreign scientists that fruitfully worked on research of problem of competitiveness of enterprises of the Zaporizhzhia district of the Zaporizhzhia region, it follows to distinguish G. Azoev, V. Arestenko, L. Balabanova, L. Dovgan, M. Kizim, I. Nszhnik, V. Ponomarenko, M. Porter, O. Tridid, R. Fathudinova. What touch industrial industry, a study of problems of production and realization of industrial products is the article of research of such scientists, as V. Geyetz, G. Pivnyak, V. Mazur, A. Bogachov, U. Makogon, A. Pikus, et al. But, without regard to popularity of this range of problems in scientific circles, variety undertaken studies, existence of the developed scientificallymethodical base of estimation of competitiveness, the problem of determination and realization of priorities of increase of competitiveness needs further development and forming of new scientific decisions with the use of logistic approach at strategic level of management of the Zaporizhzhia district of the Zaporizhzhia region enterprises.

\section{Objectives of the article}

The objective of the article is research of analysis of competitiveness of industrial enterprises of the Zaporizhzhia district of the Zaporizhzhia region.

\section{The main material of the research}

Forming of research and practice decisions in the field of the strategic management of industrial enterprise a competitiveness, in opinion of author of this article, can be carried out on the basis of selection of next base preconditions:

1) Development of industrial enterprise in a modern competition environment must be the guided, here base level of forming of tool of management development there must be a strategic level that requires forming of strategy of increase of competitiveness of industrial enterprise. Embodiment of this strategy will assist effective activity of enterprise in a competition environment [1].

2) Activity of modern industrial enterprise in a competition environment is related to the permanent changes, dynamic of influence of environment that enters into a conflict with the necessity of the corporate strategic planning, thus, strategy of increasing the competitiveness of industrial enterprise must contain elements that react on the changes of competition environment and to give possibilities of adaptation of the administrative system to these changes $[10 ; 11]$. But a management must remain strategic, id est - oriented to the achievement of strategic aims (providing of certain level of competitiveness, conquest of market positions and others like that).

3) Development of industrial enterprise in a modern competition environment it is expedient to base on distribution of the use of the logistic going near a management [4]. Strategy of increase of competitiveness of industrial enterprise must include reference-points for implementation of basic logistic tasks of minimization of expense of resources at the simultaneous achievement of a maximum of positive effect, id est to create possibilities for perfection of technical, technological, organizationally-economic, administrative processes on an enterprise, creating pre-conditions of increase of competitiveness of enterprise and for his development.

4) Showing a dynamics to the height of volume of the realized industrial products of the Zaporizhzhia district of the Zaporizhzhia region (Fig. 1), it follows to understand that each of the indicated priorities of activity of modern enterprise of industry will be realized at certain terms. From one side are market conditions, from the other is influence of the state on activity of market subjects. In industry a role of government control is often the determinative in the development with competitiveness as his basis.

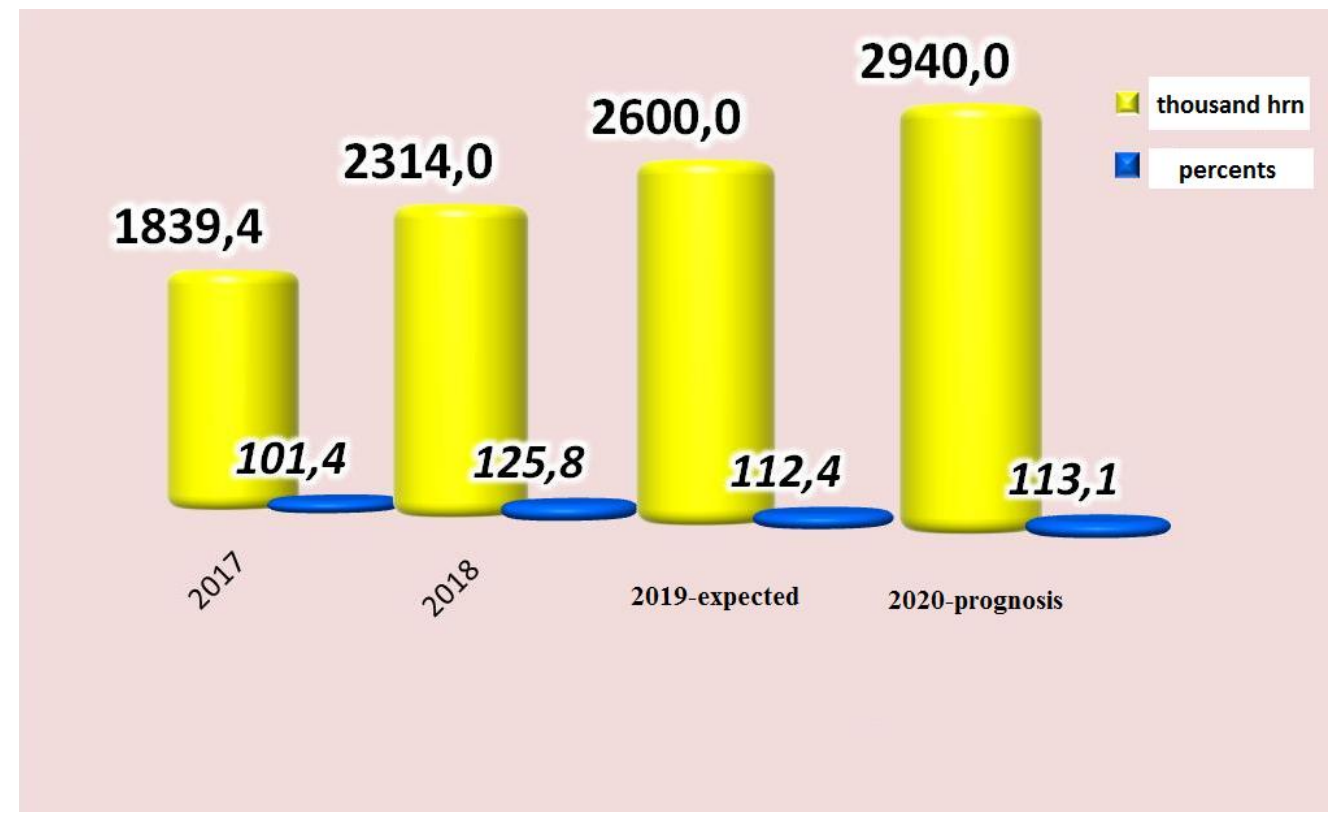

Figure 1 - Dynamics of height of volume of the realized industrial products of the Zaporizhzhia district of the Zaporizhzhia region (commodities, services) [3] 
5) The finishing stage of forming of strategic directions of increase of competitiveness of enterprises of industry is a ground of order and filling of the process of introduction of the system of the logistic providing of competitiveness of enterprises of industry. This order predetermines marketability of basic, vitally important for development, increase of competitiveness and innovative transformations of directions of activity of industrial enterprises.

Effective activity of industrial enterprises means in a competition environment, that them productive and marketing activity must maximally full answer consumer demand, to provide maximal recoupment of capital and capital goods.

A competitiveness is the major condition of economic survival of industrial enterprise [5, p. 117-118; 12], by the object of permanent attention and aim of effective management, it is characterized at the same time next signs:

- is a result from the general action of potentials of enterprise, that are in such his subsystems, as technical, social (personnel), informative, financial, administrative; in each of these systems, both threats and favourable possibilities can be stopped up for a competitiveness;

- characterizes protracted, relatively proof effectiveness of general (sinergistical) action of totality of the indicated potentials, when a competitive product "output" for an industrial enterprise is not unambigiuous, but such, that stably recurs an event;

- is the consequence of cooperation of not only own but also attracted (strangers) potentials, condition of bringing in of that is fully legitimate, that answer the rules of market menagement;
- is characterized potential, that has not only quality definiteness but also quantitative measuring, comes forward as an object of purposeful administrative influence (planning, stimulation and control);

- characterizes ability to provide not only nearest current but also remote result of activity, id est, an enterprise can be estimated as competitive in a current period, however from perspective positions - not to answer the terms of competitiveness;

- determines the combined action of factors of production, processes and results of realization of that keep indoors, as a rule, for the scopes of the accepted norms and standards for industrial products;

- most effectively arrived at in the process of realization of reasonable strategy of increase of competitiveness of industrial enterprise [6 - 8].

The problem moments of future activity are examined by strategy through the search of additional possibilities of adjustment of weak parties of activity of enterprise. On the basis of the got information the generalized model of development of strategy of development of enterprise, that is based on the reasonable choice of directions of development of enterprise of industry is developed.

For every industrial enterprise and his control system the choice of priorities of strategic development carries the applied character and is base on taking into account of influence of current indexes and end-point of different processes on the competitiveness of these enterprises, clear vision them resource possibilities and acceptability of facilities of bringing in of additional resources. Such position allows to build the graphic model of analysis and determination of priorities of development of control system by the competitiveness of enterprises of industry (Fig. 2) [12].

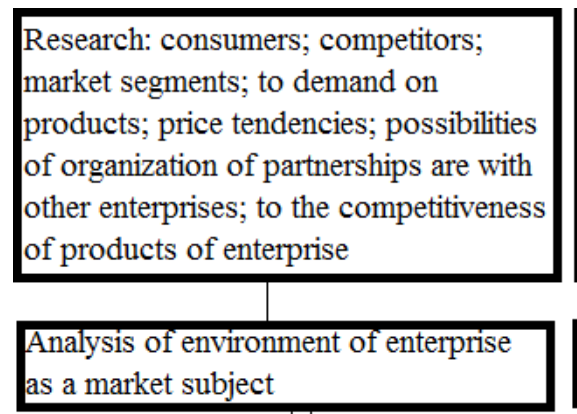
Research: products, commodities, services of
enterprise; brief-case of orders on making of
products and methods of advancement of
products; to the state of інформаційно-
aналітічного of the financial and technical,
skilled providing of enterprise

$\begin{aligned} & \text { Analysis of internal environment of enterprise } \\ & \text { as a management object }\end{aligned}$

Research of next constituents: skilled; technical; financial; informative; and also factors of development : social; political; economic; innovative; investment et al of development of enterprise

Problems, possibilities, backlogs and ways of increase of level of competitiveness of enterprise

Forming of strategic priorities of increase of competitiveness of enterprise and directions of their realization

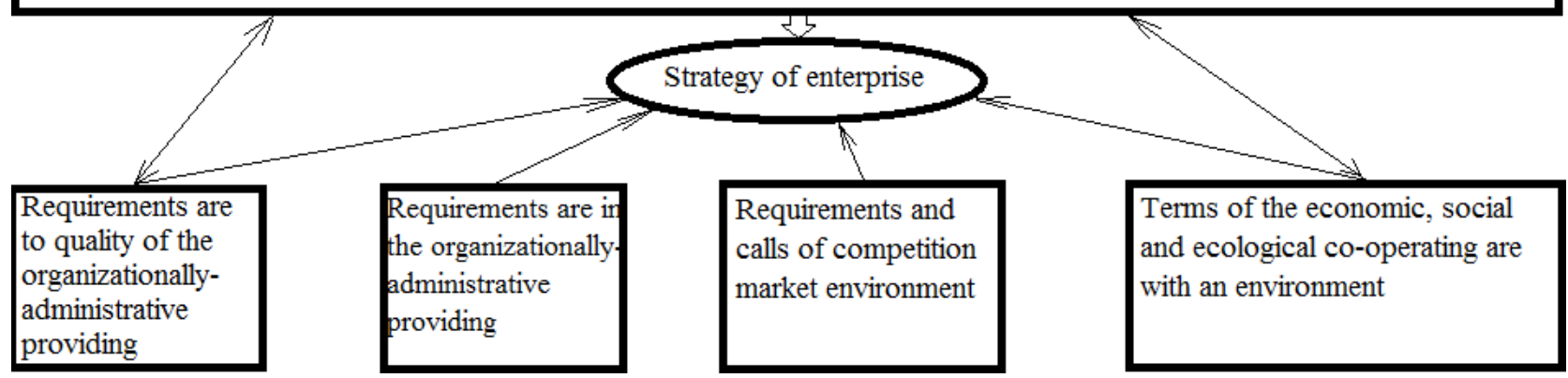

Figure 2 - Order of determination of strategic priorities of development of control system by the competitiveness of enterprises of industry [12] 
A model of increase of competitiveness of enterprises of industry on the basis of logistic approach is the element of control system by the competitiveness of enterprise and instrument of realization of strategic aims of his development, that on condition of adequate construction and use of this model assists an effective management due to:

- are synchronizations which aimed at the different levels of management organization (strategic, tactical, operative) with the simultaneous overcoming of resistance to the innovations;

- to maximally rapid advancement of ideas that is generated, from conception to commercialization with the minimum charges of resources;

- to creation of communication channels into organization with external contractors with the aim of the timely providing the specialized knowledge;

- to destruction of obstacles in co-ordination between innovative projects and command;
- to establishment of discipline for a management and providing information knowledge;

By pre-conditions of development of model of increase of competitiveness of enterprises of industry on the basis of logistic approach must be:

- it is description of starting terms, descriptions, scales of activity of enterprise, his mission;

- it is determination and estimation of actual level and dynamics of basic parameters, descriptions, indexes of control system and tendencies of their changes;

- it is determination of priorities of development that is managed and administrating subsystems in the process of action of frame case a competitiveness and of possibilities of their perfection;

- it is determination of existent problem zones, choice and ground of ways of reduction to their influence on a result or liquidations.

The chart of introduction of model of increase of competitiveness of enterprises of industry on the basis of logistic approach is presented on Fig. 3 [12].

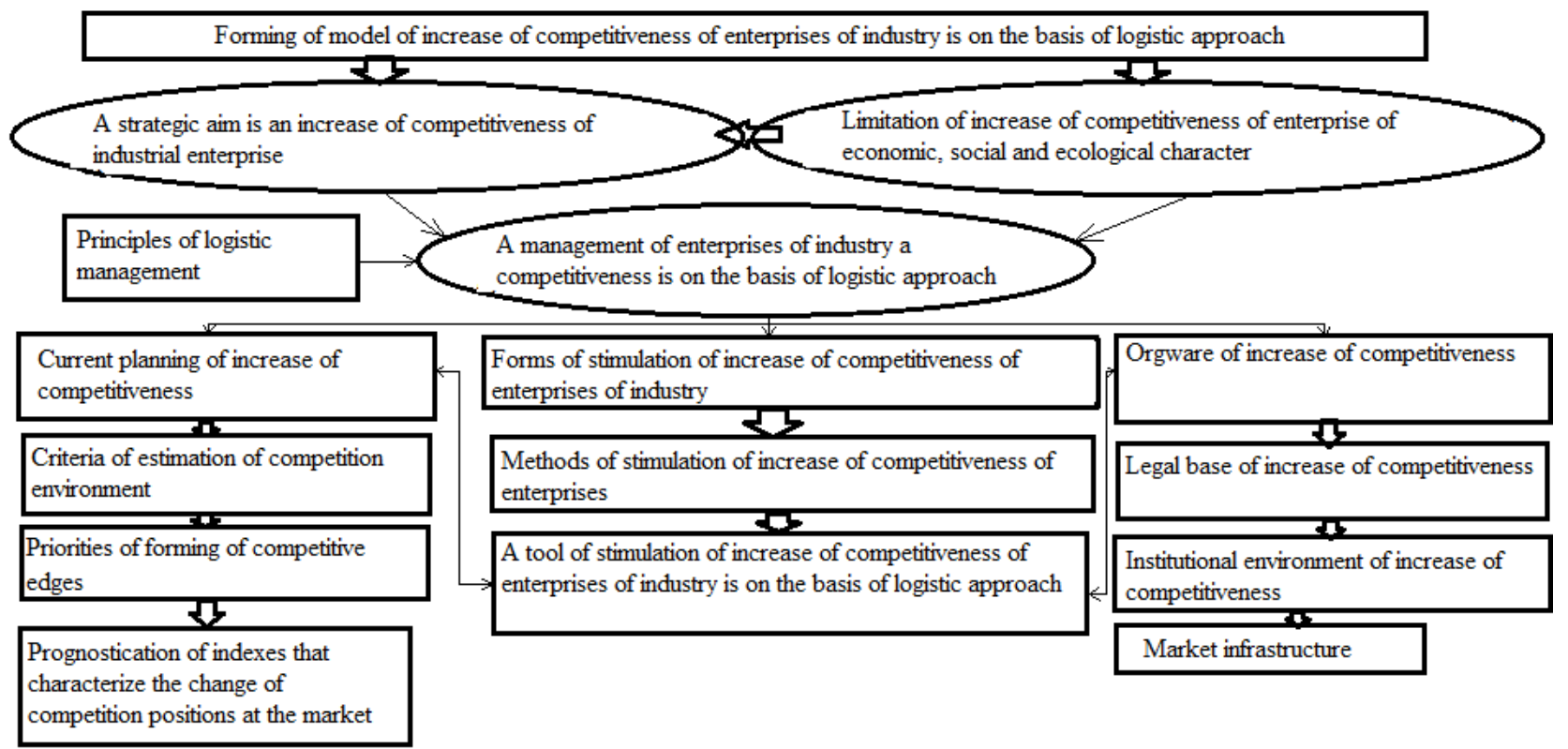

Figure 3 - A chart of introduction of model of increase of competitiveness of enterprises of industry is on the basis of logistic approach [12]

In relation to determination and estimation of actual level and dynamics of basic parameters, descriptions, indexes of control system by a competitiveness on the basis of logistic approach and tendencies of their changes, except the account of base factors of environment important is determination of list of indexes that characterize logistic activity of industrial enterprise.

At forming of model of increase of competitiveness of enterprises of industry, it is necessary to take into account on the basis of logistic approach, that realization of this model directly influences on base organizational qualities of a certain enterprise:

- ability to envisage problems and possibilities, and also accept strategic decisions, adapting to the external changes;
- a level of objectivity of estimation of new ideas is on an enterprise;

- development of internal communications;

- readiness is to the risk (ability to invest innovative processes, even in the conditions of vagueness, with the aim of improvement of activity);

- ability to manage processes that generate innovations.

In a process management of enterprise of industry a competitiveness it is necessary to take into account the system of this process, and also the base of innovative potential in forming of all system. With the aim of providing of perception of innovations by an enterprise, a management his competitiveness must provide optimal correlation of descriptions of the inculcated innovations : object of innovations; level of radicalism of innovations; 
level of adaptivity of innovations; form of perception of innovations; a level of integrity of innovations is in the process of their introduction.

11 industrial enterprises that form the index of volume of the realized industrial products (commodities, services) on the Zaporizhzhia district operate in the Zaporizhzhia district of the Zaporizhzhia region:

1) JSC «Industry»;

2) A state enterprise is «Enterprise Bilenke penal colony» of Government penitentiary function of Ukraine the Zaporizhzhia region (№ 99);

3) LTD Company «System»;

4) Private enterprise «Industrial and commercial firm «Beregynia»;

5) A branch office № 4 LTD «Ukrainian distribution company» in the Zaporizhzhia region;

6) There is limit liability company Educationalproductive association «RADUGA»;

7) Private company «ELTIZ»

8) «ELIZ» LLC, Zaporizhzhia transformers factory;

9) Private productive enterprise «Kaskad-2001»;

10) There is limit liability company «Alternative fuel company»;

11) There is limit liability company «Metalloinvest».

Enterprises engage in the production of lime, transformers and electro-reactors, awaiting-parts to the agricultural technique and commodities of folk consumption, furnitures, wares from wood, building metallic constructions and parts of constructions, oil, distilled beverages, processing of soy on oil, processing and canning of fruit and vegetables:

In 2019 the volume of the realized industrial products is expected the industrial enterprises of district in a sum a 2600,0 million hrn that folds $112,4 \% 2018$.

The prognosis index of volume of the realized industrial products on 2020 is envisaged in a sum a 2940,0 million hrn, that on $113,1 \%$ more expected for 2019 .

By the state on in 01.12.2019 63491,4 thousand hrn came in the general fund of local budgets of district., that to the specified plan on January - November, 2019 (58892,9 thousand hrn), presents $107,8 \%$. Overfulfilling made a 4 598,5 thousand hrn.
Expense part of budget of district is executed on a general fund on $83,3 \%$ to the specified annual plan. At the specified annual plan there is a 321681,2 thousand hrn. on a year, the 268089,2 thousand hrn of charges is executed.

Account payable on the protected items of expenses, that is financed due to money of local budgets, by the state on in 01.12.2019 is absent [3].

\section{Conclusions}

Summarizing, it is possible to mark, that successful development of industrial enterprise in the Zaporizhzhia district of the Zaporizhzhia region is possible only on condition of valuable activity of all totality of interdependent economic mechanisms, and also forming and realization of the system of strategies of enterprises of industry on the basis of logistic approach. Absence or improper functioning even of one link in the system of development of enterprise of industry is accompanied by negative microeconomic changes, deformations in the construction of productive relations, productive forces and others like that, that in the end influences on a competitiveness and dynamics of development of these enterprises.

Reasonable totality of mechanisms and going near a choice from existent alternatives, forming and realization of strategy of increase of competitiveness of enterprises of industry of the Zaporizhzhia district of the Zaporizhzhia region predetermines possibility of effective, less resource-consuming, dynamic, in the maximally possible degree of the forecast realization of basic, vitally important for the increase of competitiveness and innovative transformations of activity of these enterprises.

Reasonable totality of mechanisms and going near a choice from existent alternatives, forming and realization of strategy of increase of competitiveness of enterprises of industry of the Zaporizhzhia district of the Zaporizhzhia region predetermines possibility of effective, less resource-consuming, dynamic, in the maximally possible degree of the forecast realization of basic, vitally important for the increase of competitiveness and innovative transformations of activity of these enterprises.

\section{References}

1. Stok, Dzh. R. and Lambert, D.M. (2005), Strategicheskoe upravlenie logistikoy [Strategic logistics management], INFRA-M, Moscow, Russia.

2. Ilyashenko, S.N. and Shipulina Yu.S. (2010), “Analysis of market opportunities of innovative development of the enterprise in terms of fuzzy evaluation of factors internal and external environment", Visnik SumDU.Series: Economy, vol. 1, pp. 97-102.

3. The program of socio-economic and cultural development of the Zaporizhzhia Regional Council is on 2020 [Online], available at: at: http://zprada.gov.ua/rishennia_radi/2171piatdesiat_persha_sesiia_somogo_sklikannia.html

4. Tkachova A.V. (2012), "Cluster analysis of metallurgical enterprises from manufacturing, financial, economic and logistic performance", Visnik Zaporizkogo natsionalnogo unIversitetu, [Online], vol. 1(13), available at: http://web.znu.edu.ua/herald/issues/2012/eco-1-2012/037-44.pdf

5. Zhamoyda, O.A. (2009), "Methodological features determining the competitiveness of industrial enterprises", AktualnI problemi ekonomiki, vol. 1, pp. 110-118. 
6. Kataev, O. (2012), "Provisions of revamping energy intensive mining and smelting complex Donbass", Ekonomika Ukrayini, vol. 2, pp. 84-88.

7. "Metallurgy: salvation in the development of the internal market", Golos Ukrayini, [Online], available at: http://golosukraine.com/publication/ekonomika/parent/21801-metalurgiya-poryatunok-u-rozvitku-vnutrishnogorin, (Accessed).

8. Pikus, A.Yu. (2011), "Metallurgical industry Ukraine: trends and prospects", Aktualni problemi ekonomiki, vol. 4(118), pp. 92-102.

9. Bezverkha I. Strategic priorities of increasing competitiveness of metallurgical enterprises based on logistic approach / I. Bezverkha // ДДАЕУ: Electronic magazine «Effective economy», №11, 2015

10. Landina, T.V. (1994), Organizatsiyno-ekonomichni mehanizmi adaptatsiyi pidpriemstva do umov rinku [Organizational-economic mechanism of enterprise adaptation to market conditions], Naukova dumka, Kyiv, Ukraine.

11. Sokolova, L.V. (1996), Adaptatsiya predpriyatiy k usloviyam ryinka [Adaptation of enterprises to the market conditions], FORT, Kharkov, Ukraine.

12. Solyanik, L.G. (2011), "Evaluation of the financial component of the competitiveness of the metallurgical industry", Finansi galuzi ta pidpriemstva, [Online], vol. 2, available at: http://eaf.nmu.org.ua/ua/pro_kaf, (Accessed). 